\title{
Pathogenesis of Herpesvirus anguillae (HVA) in juvenile European eel Anguilla anguilla after infection by bath immersion
}

\author{
Basav N. Hangalapura ${ }^{1}$, Rob Zwart ${ }^{2}$, Marc Y. Engelsma1, ${ }^{1}$ Olga L. M. Haenen ${ }^{1, *}$ \\ ${ }^{1}$ NRL for Fish and Shellfish Diseases, CIDC-Lelystad, Wageningen UR, PO Box 2004, 8203 AA Lelystad, The Netherlands \\ ${ }^{2}$ Animal Sciences Group, Wageningen UR, Division Infectious Diseases, Laboratory of Pathology, PO Box 65, \\ 8200 AB Lelystad, The Netherlands
}

\begin{abstract}
A clinical infection in post-larval (glass) European eels Anguilla anguilla was successfully induced after artificial bath immersion with Herpesvirus anguillae (HVA), isolated from diseased European eel. HVA caused a clinical infection after 7 d post-inoculation (pi); virus was detected by polymerase chain reaction (PCR) from Day 1 pi; virus isolation was positive from Day 7 pi, and HVA antigen was detected by immunohistochemistry in gills and stomach from Day 4 pi. Tissue changes were found by histological examination in gills and skin from Day 4 pi. In general, there was good correlation in the timing of the clinical signs, PCR, virus isolation, immunohistochemistry and histopathology results, although PCR, histopathology and immunohistochemistry were the first positive tests. HVA was first detected in skin and stomach, followed by gills, and later heart and intestine, whereas HVA was detected persistently in gills and skin. Koch's postulates were fulfilled. For diagnosis of HVA infections, clinical pathology combined with virus isolation and/or PCR are recommended.
\end{abstract}

KEY WORDS: European eel · Herpesvirus anguillae $\cdot$ HVA $\cdot$ Pathogenesis $\cdot$ Virus isolation · PCR · Immunohistochemistry · Histopathology

\section{INTRODUCTION}

Herpesviruses are the most highly represented group of DNA viruses found in fishes (Hedrick \& Sano 1989). Sano et al. (1990) characterised a herpesvirus isolated from 2 species of diseased eel, Anguilla anguilla and A. japonica, and designated the virus as Herpesvirus anguillae (HVA), also called Anguillid herpesvirus 1. Ueno et al. (1992) described the characteristics of a herpes-like particle isolated from Japanese eel A. japonica cultured in Taiwan, and tentatively designated the virus as EHVF (eel herpesvirus in Formosa). The morphology and size of EHVF particles were very similar to those of HVA, and the ranges of susceptible host cell lines for these 2 viruses were identical (Ueno et al. 1992). Ueno et al. (1996) com- pared the serological and virological characteristics of HVA and EHVF and determined that the viruses shared a high degree of similarity. In pathogenicity studies, Kobayashi \& Miyazaki (1997) demonstrated that infection of Japanese eel A. japonica with HVA resulted in disease. Viral disease outbreaks were reported from 1993 to 1995 in farmed Japanese eel in Japan, where a herpesvirus could be isolated (Lee et al. 1999). In 1998, HVA was isolated for the first time in The Netherlands and in Europe; soon after, more than 18 disease outbreaks followed in farmed European eel A. anguilla (Davidse et al. 1999, Haenen et al. 2002). Van Nieuwstadt et al. (2001) showed, by virus isolation, the persistence of HVA in cultured eel from a clinically healthy stock. Additionally, increased virus shedding upon treatment with the stress hormone 
dexamethasone was reported, and the antibody response to HVA was studied. Rijsewijk et al. (2005) reported the antigenic relationship of the Dutch and Japanese isolates to $H$. anguillae. Shih et al. (2003) experimentally infected Japanese eels A. japonica with HVA by injection, and this resulted, after only $>7 \mathrm{wk}$, in gill and liver disease. To our knowledge, no pathogenesis studies in European eel infected with HVA by bath immersion have been published so far.

The present study investigated the susceptibility of juvenile European eel Anguilla anguilla to infection with a European strain of HVA by bath immersion, and its pathogenesis in these eels. We successfully induced an experimental clinical HVA infection in post-larval (glass) eels via bath immersion with a HVA strain isolated from diseased farmed European eel. An immunohistochemical technique was established to study the pathogenesis of HVA. We used PCR (Rijsewijk et al. 2005) and virus isolation techniques to confirm the presence or absence of virus in experimentally exposed eels. The results of these techniques were compared in a time-course study. Furthermore, we studied the histopathological changes caused by HVA infection in glass eels. Clinical pathology, virus isolation, and PCR were found to be the most suitable methods for diagnosis of HVA infections.

\section{MATERIALS AND METHODS}

Cells and virus. The eel kidney cell line, EK-1, developed by Chen et al. (1982) was used throughout this study. EK-1 cells were cultured at $26^{\circ} \mathrm{C}$ according to Davidse et al. (1999). The Dutch HVA virus isolate no. 500138 (Van Nieuwstadt et al. 2001) was replicated in EK-1 cells at $26^{\circ} \mathrm{C}$. After $100 \%$ cytopathic effect (CPE) developed, the virus was concentrated by ultracentrifugation $\left(180000 \times g\right.$ for $2 \mathrm{~h}$ at $\left.10^{\circ} \mathrm{C}\right)$ to get a final concentration of $10^{8} \mathrm{TCID}_{50} \mathrm{ml}^{-1}$, and this was used for the experimental infections.

Fish. For experimental infection, 380 virus-free, 2 mo old glass eels Anguilla anguilla $(5.1 \pm 1.88 \mathrm{~g})$ were bought from a HVA-free Swedish eel farm. From this batch, 15 eels were used directly for pre-testing to confirm absence of virus and 5 were kept in reserve. Two groups (an HVA-infected group and a negative control group), with 180 eels each, were kept in separate rooms in 1001 aquaria, filled with oxygenated tap water. They were acclimatised for $2 \mathrm{~d}$. Glass eels were fed ad libitum with pelleted glass eel feed (Trouw), and the water temperature was maintained at $23 \pm 2.2^{\circ} \mathrm{C}$ (negative control) and $24 \pm 2.2^{\circ} \mathrm{C}$ (HVA inoculated group) throughout the experiment and was recorded daily. Approximately $50 \%$ of the water from each aquarium was renewed daily with tap water preheated to $25^{\circ} \mathrm{C}$. Hiding places for the eels were provided by placing PVC pipes at the bottom of the aquaria. Low light intensity was maintained in the aquarium rooms throughout the study.

Experimental design and sampling. On arrival, 15 eels were randomly selected, euthanized with 0.4 to $0.5 \mathrm{ml}$ 2-phenoxy-ethanol $\mathrm{l}^{-1}$ water, and weighed. Eel gills and organs were collected aseptically, and tested for HVA by virus isolation and PCR (Rijsewijk et al. 2005). After 2 d acclimatization, the eels for HVA infection were exposed to HVA (strain no. 500138) by bathing them for $8 \mathrm{~h}$ in $89 \mathrm{l}$ water, to which $100 \mathrm{ml}$ viral suspension of $10^{7.84} \mathrm{TCID}_{50} \mathrm{ml}^{-1}$ was added. This resulted in exposure of the eels to a final titre of $10^{4.89}$ TCID $_{50} \mathrm{ml}^{-1}$. Similarly, the negative control group was exposed to $100 \mathrm{ml}$ cell culture medium (Leibovitz L-15) without virus, in $100 \mathrm{l}$ of water. After the exposure period, the aquarium water of both groups was renewed totally. Eels were checked daily for clinical signs and mortality.

At Day 0, 5 eels were sampled from the negative control group and processed for immunohistochemistry. Subsequently, 10 eels (5 for virus isolation and PCR, 5 for immunohistochemistry) were sampled at 1, $3,8,15,17$, and 22 d post-inoculation (dpi). From the HVA-infected group, 10 eels (5 for virus isolation and PCR and 5 for immunohistochemistry) were sampled at $1,2,3,4,7,9,11,14,16,18$ and 21 dpi. Additionally, 5 eels were sampled for histological examination on arrival of the eels (Day $-3 \mathrm{pi}$ ), from the negative control group at 10 and $22 \mathrm{dpi}$, and from the HVA-infected group at $4,9,11,16$, and $18 \mathrm{dpi}$. The experiment was terminated at $22 \mathrm{dpi}$.

Diseased eels showing ulcers were additionally sampled and tested for bacterial infection by taking cotton swab specimens from the ulcers and internal organs, inoculating these onto sheep blood agar plates, and incubating them at $22^{\circ} \mathrm{C}$ for 4 to $7 \mathrm{~d}$. Eels sampled for virus isolation and PCR were euthanized with 2-phenoxy-ethanol in water. Using an asceptic technique, they were cut into small transversal parts (excluding anterior mouth and tail) which were pooled and stored at $-80^{\circ} \mathrm{C}$ until further processed. Eels sampled for immunohistochemistry were euthanized similarly. They were cut into 6 transversal parts from the tip of the mouth to just behind the anus. Two blocks, each with 3 of the 6 parts of the eel, were quickly frozen in liquid nitrogen and stored at $-20^{\circ} \mathrm{C}$ for immunohistochemistry. Eels sampled for histology were euthanized similarly and cross-sectioned into 3 equal parts excluding the tail, and fixed in $10 \%$ buffered formaldehyde. After at least $4 \mathrm{~d}$ of fixation at room temperature, tissues were dehydrated, paraffin embedded, and histological sections (5 $\mathrm{m}$ thick) were prepared, stained with haematoxylin and eosin and examined by light 
microscopy. At the end of the experiment (Day 22 pi) all remaining eels were all euthanized with 2-phenoxy-ethanol.

Virus isolation and PCR. Individual eels were used for virus isolation. The eels were ground separately with sterile sand in sterile mortars and pestles and a $10 \%(\mathrm{w} / \mathrm{v})$ suspension was made according to Haenen et al. (2002). Two passages were performed in EK-1 cell cultures in 6-well plates, as described by Davidse et al. (1999). CPE occurred after a total of $14 \mathrm{~d}$, the samples were considered to be negative for virus. If $\mathrm{CPE}$ occurred, the culture plates were frozen at $-70^{\circ} \mathrm{C}$ for at least one night, thawed at room temperature, and the cell lysates were centrifuged for $10 \mathrm{~min}$ at $2000 \times g$ at $10^{\circ} \mathrm{C}$, after which the supernatant was examined by PCR according to Rijsewijk et al. (2005). The original $10 \%$ suspensions of the individual eels, made for virus isolation, were also all tested by the HVA PCR (Rijsewijk et al. 2005).

Immunohistochemistry. An immunohistochemical (indirect immunoperoxidase staining technique) test to detect HVA in eel tissues was developed based on the basic principles described by Bourne (1983). Cryosections ( $8 \mu \mathrm{m}$ thick) of eel tissues were cut with a cryostat (Leica ${ }^{\circledR}$ ), fixed in acetone with $0.01 \% \mathrm{H}_{2} \mathrm{O}_{2}$ for $10 \mathrm{~min}$, and air dried at room temperature before being placed in storage at $20^{\circ} \mathrm{C}$ until further processing. All incubations were done at room temperature in a humid chamber. Endogenous peroxidase activity in eel cryosections was prevented by pre-incubating the cryosections with $3 \% \quad \mathrm{H}_{2} \mathrm{O}_{2}$ in absolute methanol for $20 \mathrm{~min}$. Non-specific antibody binding sites were blocked by incubating the sections with a solution of $10 \%(\mathrm{v} / \mathrm{v})$ normal goat serum and $5 \%(\mathrm{w} / \mathrm{v})$ bovine serum albumin (BSA, Fraction V, Sigma, Cat. no. A4503) for $10 \mathrm{~min}$ in phosphate-buffered saline (PBS; $\mathrm{pH}$ 7.4). The slides were blotted dry and incubated with the primary rabbit anti-HVA serum (Van Nieuwstadt et al. 2001) at a dilution of 1:1000 in 5\% (v/v) normal horse serum in PBS for $60 \mathrm{~min}$. After $2 \times 5 \mathrm{~min}$ washing in PBS with $0.05 \%$ Tween-20, the secondary antibody, goat anti-rabbit immunoglobulin conjugated with horseradish peroxidase (HRP, DAKO A/S, Cat. no. P0448) diluted 1:100 in 1\% BSA in PBS, was added and incubated for $30 \mathrm{~min}$. After washing with PBS, the substrate (diaminobenzidin $/ \mathrm{H}_{2} \mathrm{O}_{2}$ ) was added for 3 min to allow the stained end-product to develop. After washing in demineralised water, sections were counterstained with haematoxylin, dehydrated in a series of increasing concentration of ethanol $(50,70,90,100$, $100 \%), 2$ baths of pure xylene, and finally mounted using euxitt ${ }^{\circledR}$ (Klinipath). The endpoint dilution of primary antibody that gave a positive stain distinguishable from the background was determined by a checker board titration.

\section{RESULTS}

The individual results of clinical signs, virus isolation and PCR testing, and for the eels sampled for clinical signs and immunohistochemistry are presented in Table 1.

Clinical signs. Eels from the negative control group showed no clinical signs and no mortality during the experiment. The eels from the HVA-infected group showed a clinical signs of disease: At Day 3 pi, first clinical signs, such as haemorrhages in the ventral wall and the throat of 1 eel, were observed but no samples were taken. At Day $7 \mathrm{pi}$, haemorrhages on the operculum and the ventral wall were observed. At Day 11 pi, haemorrhages in the skin of the head, lower jaw, operculum and pectoral fins were observed (Fig. 1). Thereafter, additional haemorrhages were observed on the ventral surface down to the tail. Clinical signs were seen throughout the duration of the experiment, until 21 dpi. Although eels were regularly euthanized for sampling, the proportion of eels showing clinical signs was $15 \%$ (27 of 180 HVA-inoculated eels).

Virus isolation. Virus isolations on eels sampled upon arrival from Sweden (Day -3 pi) were negative. All eels from the negative control group tested negative for HVA by virus isolation throughout the experiment. HVA was isolated from eels of the HVAinfected group, sampled at Days 7, 9, 11, 14, 16 and 21 pi. At Days 1, 2, 4, and 18 pi the sampled eels from this group were negative by virus isolation (Table 1).

PCR. No HVA could be detected by PCR in the eels sampled upon arrival from Sweden (Day -3 pi). All eels from the negative control group tested negative for HVA by PCR throughout the experiment. In the HVA-infected group, HVA was detected by PCR in individual eels from Day 1 pi until the end of the experiment (Day 21 pi) (Table 1). Almost all sampled eels were HVA-positive in this group from Day 7 until Day 21 pi.

Bacteriology. Only 2 diseased eels showed skin lesions and were tested for bacterial infection at Day 7 pi. Specimens of skin lesions, incubated at $22^{\circ} \mathrm{C}$ were multi-bacterial. No bacteria were isolated from liver, spleen, and kidney samples from these eels.

Immunohistochemistry. Data from individual tissues that tested positive for HVA immunohistochemistry are presented in Table 1, and qualitative data obtained at various times post-inoculation are in Table 2. All eels sampled from the negative control group for immunohistochemistry were found negative for HVA-specific staining throughout the experiment. The first HVA-positive eel by immunohistochemistry was seen at Day 4 pi (skin and stomach, Fig. 2a), 
Table 1. Anguilla anguilla. Clinical signs, virus isolation (VI), PCR, and immunohistochemistry (IHC) results from juvenile European eels infected with Herpesvirus anguillae (HVA) by bath immersion. The eels sampled for VI and PCR were different than those sampled for IHC. dpi: days post-inoculation. Clinical signs, PCR, and IHC results: (-) negative; $(+/-)$ weak positive; $(+)$ positive. VI results: (+) positive for HVA (only syncytia in cell culture); (++) positive for HVA (moderate CPE); (+++) positive for HVA (complete CPE)

\begin{tabular}{|c|c|c|c|c|c|c|c|}
\hline \multirow{2}{*}{$\begin{array}{l}\text { Day of } \\
\text { sample } \\
\text { (dpi) }\end{array}$} & \multicolumn{4}{|c|}{ — Virus isolation and PCR } & \multicolumn{3}{|c|}{ - Immunohistochemistry } \\
\hline & Eel no. & Clinical signs & VI result & PCR result & Eel no. & Clinical signs & $\begin{array}{c}\text { IHC result, } \\
\text { affected organs }\end{array}$ \\
\hline \multirow[t]{5}{*}{$-3^{\mathrm{a}}$} & 1 & - & - & - & 6 & - & - \\
\hline & 2 & - & - & - & 7 & - & - \\
\hline & 3 & - & - & - & 8 & - & - \\
\hline & 4 & - & - & - & 9 & - & - \\
\hline & 5 & - & - & - & 10 & - & - \\
\hline \multirow[t]{5}{*}{1} & 1 & - & - & - & 6 & - & - \\
\hline & 2 & - & - & - & 7 & - & - \\
\hline & 3 & - & - & + & 8 & - & - \\
\hline & 4 & - & - & - & 9 & - & - \\
\hline & 5 & - & - & + & 10 & - & - \\
\hline \multirow[t]{5}{*}{2} & 1 & - & - & - & 6 & - & - \\
\hline & 2 & - & - & $+/-$ & 7 & - & - \\
\hline & 3 & - & - & + & 8 & - & - \\
\hline & 4 & - & - & + & 9 & - & - \\
\hline & 5 & - & - & - & 10 & - & - \\
\hline \multirow[t]{5}{*}{4} & 1 & - & - & - & 6 & - & - \\
\hline & 2 & - & - & + & 7 & - & - \\
\hline & 3 & - & - & - & 8 & - & - \\
\hline & 4 & - & - & - & 9 & - & + skin, stomach \\
\hline & 5 & - & - & - & 10 & - & - \\
\hline \multirow[t]{5}{*}{7} & 1 & + & + & + & 6 & - & - \\
\hline & 2 & + & + & + & 7 & - & - \\
\hline & 3 & + & ++ & + & 8 & - & + gills \\
\hline & 4 & - & - & - & 9 & - & - \\
\hline & 5 & - & ++ & + & 10 & - & - \\
\hline \multirow[t]{5}{*}{9} & 1 & - & +++ & + & 6 & - & - \\
\hline & 2 & - & +++ & + & 7 & - & - \\
\hline & 3 & - & ++ & $+/-$ & 8 & - & + gills \\
\hline & 4 & - & - & + & 9 & - & - \\
\hline & 5 & - & ++ & + & 10 & - & - \\
\hline \multirow[t]{5}{*}{11} & 1 & - & +++ & + & 6 & - & - \\
\hline & 2 & - & +++ & + & 7 & - & + skin, gills, heart \\
\hline & 3 & - & ++ & + & 8 & - & - \\
\hline & 4 & + & +++ & + & 9 & - & +gills \\
\hline & 5 & + & +++ & + & 10 & - & - \\
\hline \multirow[t]{5}{*}{14} & 1 & + & +++ & + & 6 & + & + gills, gill cavity \\
\hline & 2 & + & +++ & + & 7 & + & + gills, gill cavity, heart \\
\hline & 3 & + & ++ & + & 8 & + & + gills \\
\hline & 4 & + & ++ & + & 9 & + & + gills \\
\hline & 5 & + & ++ & + & 10 & - & + skin \\
\hline \multirow[t]{5}{*}{16} & 1 & - & + & + & 6 & + & + gills \\
\hline & 2 & + & + & + & 7 & + & + gills \\
\hline & 3 & - & +++ & + & 8 & + & + gills \\
\hline & 4 & + & ++ & + & 9 & - & - \\
\hline & 5 & - & ++ & + & 10 & - & - \\
\hline \multirow[t]{5}{*}{18} & 1 & + & - & + & 6 & + & - \\
\hline & 2 & - & - & + & 7 & - & - \\
\hline & 3 & - & - & + & 8 & - & - \\
\hline & 4 & - & - & $+/-$ & 9 & - & + heart \\
\hline & 5 & - & - & + & 10 & - & - \\
\hline \multirow[t]{5}{*}{21} & 1 & + & +++ & + & 6 & - & - \\
\hline & 2 & + & ++ & + & 7 & - & - \\
\hline & 3 & - & +++ & + & 8 & - & - \\
\hline & 4 & - & ++ & + & 9 & - & + skin \\
\hline & 5 & - & - & - & 10 & - & + skin and intestine \\
\hline
\end{tabular}



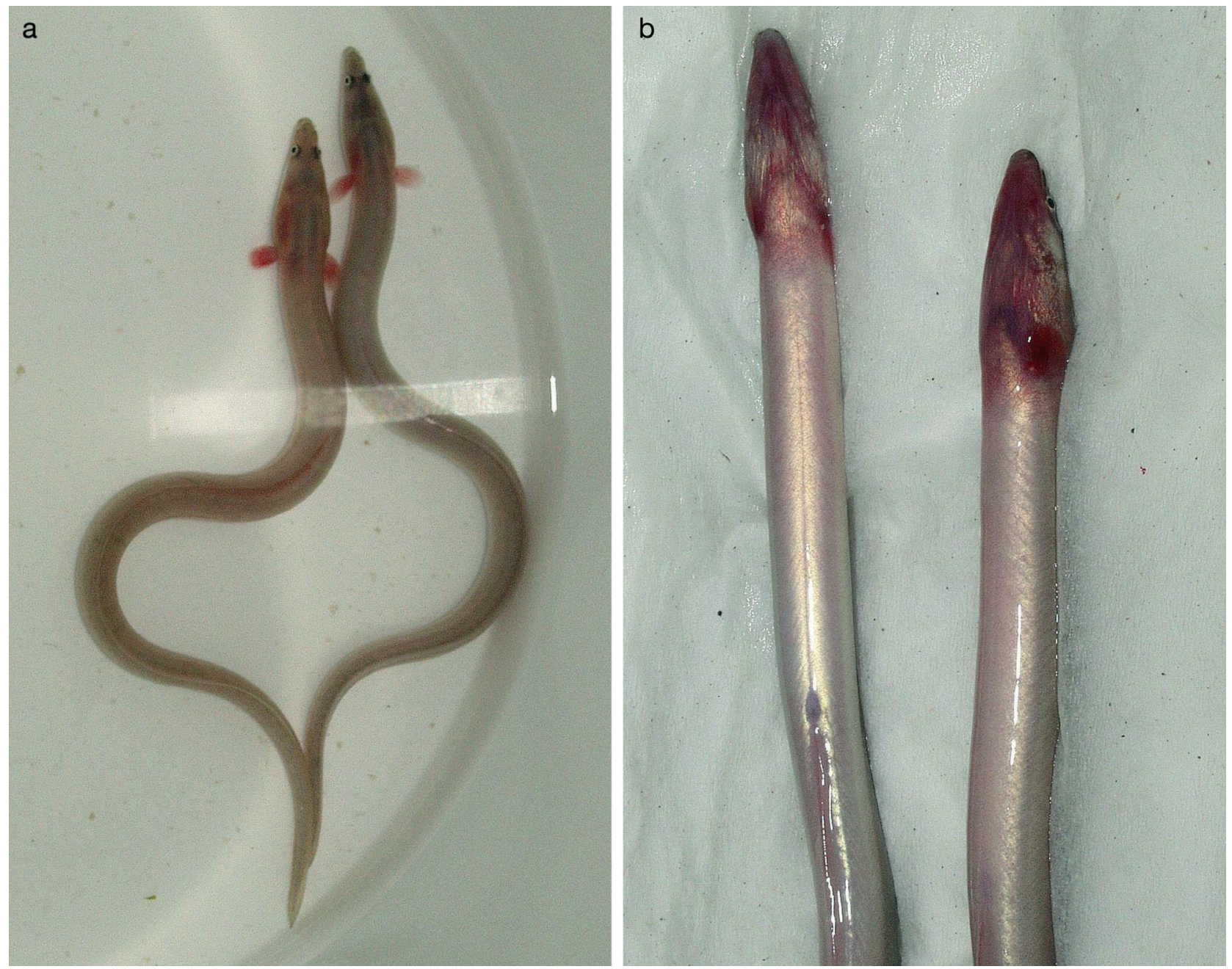

Fig. 1. Anguilla anguilla. Clinical signs in juvenile European eel $11 \mathrm{~d}$ after bath infection with Herpesvirus anguillae (HVA). (a) Haemorrhages on the operculum and pectoral fins; (b) haemorrhages on the lower jaw, belly, and anal fin (ventral view)

followed by one at Day $7 \mathrm{pi}$ (gills) and one at $9 \mathrm{pi}$ (gills). At Day 11 pi 2 of the 5 sampled eels were positive (gills, Fig. 2b; skin, Fig. 2c; and heart, Fig. 2d). Up to Day 11 pi no clinical signs were observed in the sampled eels for immunohistochemistry. At Day 14 pi the sampled eels showed clinical signs and all 5 were positive (gills, skin); at Days 18 and 21 pi 1 (heart) and 2 (skin and gut) were found positive, respectively, but without clinical signs.

Histopathology. In the eels sampled upon arrival from Sweden (Day $-3 \mathrm{pi}$ ), and those of the negative control group sampled at Days 10 and 22 pi, no abnormalities were seen by light microscopy in the histological sections. In eels from the HVA-infected group, abnormalities such as gill hyperplasia and skin necrosis were seen from Day 4 pi, and haemorrhages in skin, gills, muscle, and liver in a later phase (Days 9, 11, and 16 pi). The changes often coincided with positive immunohistochemistry results in the same tissues (Table 2, Fig. 3).

Comparison among assays and clinical signs. There was a good correlation between the presence of clinical signs and positive results of the samples in the HVA $\mathrm{PCR}$, virus isolation, immunohistochemistry, and histopathology. The first eels with clinical signs were observed at Day 3 pi, but no samples were taken on that day. The majority of the HVA-infected group looked healthy throughout the experiment. However, some clinically healthy eels were found positive for HVA. A few samples taken on Days 1 pi (2 of 5), 2 pi (3 of 5) and 4 pi (1 of 5) were positive in the PCR test but were negative by virus isolation. All samples from Days 11, 14, and 16 pi were positive for HVA both by PCR and virus isolation. The peak of the disease, as judged by a combination of clinical signs, virus isolation and PCR positive results was seen at Day 14 pi. 
Table 2. Anguilla anguilla. Qualitative immunohistochemistry (IHC) and histopathology results of juvenile European eels at different times following bath infection with Herpesvirus anguillae (HVA). dpi: days post-inoculation. Eels from the negative control groups were all negative by IHC and showed no abnormalities by histology. nd: not done

\begin{tabular}{|c|c|c|}
\hline $\begin{array}{l}\text { Day of } \\
\text { sample (dpi) }\end{array}$ & IHC-positive & Histopathology-affected organ or tissue \\
\hline$-3^{\mathrm{a}}$ & None & No abnormalities \\
\hline 1 & None & nd \\
\hline 2 & None & nd \\
\hline 4 & Skin and stomach epithelium & Skin infiltrations, mild gill hyperplasia \\
\hline 7 & Gills & nd \\
\hline 9 & Gills & Moderate skin necrosis and gill hyperplasia, mild skin haemorrhages \\
\hline 11 & Skin epithelium, heart and gills & $\begin{array}{l}\text { Moderate gill hyperplasia with haemorrhages, congested and necrotic skin } \\
\text { with haemorrhages, congested epithelium of inner mouth and gill cavity, } \\
\text { haemorrhages in the adipose tissue, hyperaemia in the muscle, mild kidney } \\
\text { necrosis }\end{array}$ \\
\hline 14 & $\begin{array}{l}\text { Gills, inner layer of operculum, } \\
\text { gill cavity and skin epithelium }\end{array}$ & nd \\
\hline 16 & Gills & $\begin{array}{l}\text { Severe skin necrosis with larger haemorrhages at the base of the dermis, } \\
\text { gill hyperplasia, moderate necrosis of inner mouth and gill cavity, mild liver } \\
\text { necrosis with hyperaemia, haemorrhages in the muscle }\end{array}$ \\
\hline 18 & Heart & $\begin{array}{l}\text { Some gill hyperplasia, severe skin haemorrhages and moderate necrosis at } \\
\text { the base of the dermis, mild necrosis of the spleen, haemorrhages in the } \\
\text { muscle, adipose and connective tissues }\end{array}$ \\
\hline 21 & Skin and intestine epithelium & nd \\
\hline
\end{tabular}

\section{DISCUSSION}

HVA infection is associated with disease in juvenile European eels Anguilla anguilla, especially under stressful conditions at eel farms (Van Nieuwstadt et al. 2001, Haenen et al. 2002). In the present study, we induced a clinical infection with HVA in HVA-free glass eels from Sweden at 23 to $24^{\circ} \mathrm{C}$. As far as we know, the present study comprises the first successful artificial bath infection with HVA reported in European eel, and no additional stress factors were necessary to induce disease. Our study proves that HVA can infect naive juvenile European eel via the water, which is thought to be the natural infection route, and may cause disease in these eels.

Previously reported experimentally induced infections with HVA were all caused by injection. Kobayashi \& Miyazaki (1997) injected Anguilla japonica intracutaneously with HVA, which resulted in clinical disease in fish held at $25^{\circ} \mathrm{C}$, but with no mortality. Lee et al. (1999) injected HVA into Japanese eels of 25 to $40 \mathrm{~g}$ weight intramuscularly, and of $130 \mathrm{~g}$ weight into the gill arch. Disease developed at $25^{\circ} \mathrm{C}$ in both groups, but mortality was seen only in the small eels that showed gill necrosis. The larger eels showed mild gill necrosis only. Shih et al. (2003) injected juvenile $A$. japonica weighing $15 \mathrm{~g}$ intraperitoneally with HVA, but clinical disease was not observed during the $7 \mathrm{wk}$ period of the experiment. In the study of Van Nieuwstadt et al. (2001), European eels (150 to $200 \mathrm{~g}$ ) were injected intraperitoneally with HVA, but no disease resulted at $23^{\circ} \mathrm{C}$ during $46 \mathrm{~d}$, even at a higher titre after injection with the stress hormone dexamethasone, although re-isolation of virus was possible. The fact that diseased eels were not obtained in their infection experiment while disease was induced in the present study might be explained by the use of smaller sized and HVA-naïve eels in our study. Additionally, the European eels in the study of Van Nieuwstadt et al. (2001) were sourced from southwest Europe, and probably had been pre-exposed to HVA.

In the present study we used a virus isolate from diseased eels to expose, by immersion, healthy glass eels which developed disease and from which the virus HVA could be re-isolated, therefore fulfilling Koch's postulates (Evans 1976) for HVA in European eel. HVA infection did not cause mortality, which supports the non-lethal nature of this virus as reported by Kobayashi \& Miyazaki (1997) in Japanese eel Anguilla japonica.

All the clinically diseased eels, except one eel sampled from the infected group at Day 18 pi which was negative by virus isolation, were positive for HVA, both by PCR and virus isolation (Table 1). From Day 7 pi, some eels were positive by virus isolation without showing clinical signs. The results of this pathogenesis experiment support the idea that presence of clinical signs is an indication of establishment of the virus in the host. In the present study with European eel, the first clinical signs were haemorrhages on the opercu- 

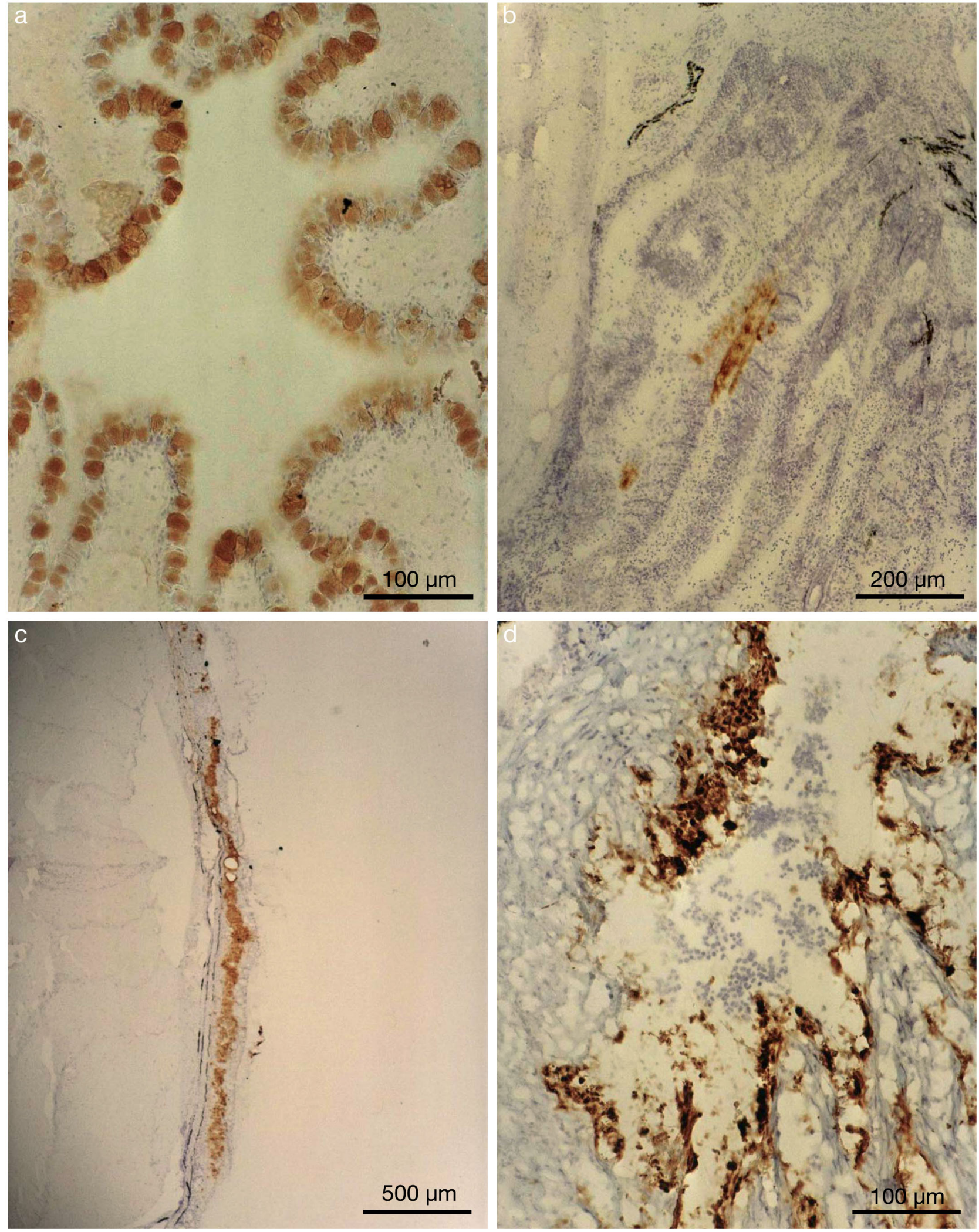

Fig. 2. Anguilla anguilla. Immunohistochemistry results after bath infection of juvenile European eels with Herpesvirus anguillae (HVA). Positive staining for HVA in (a) the stomach epithelium 4 days post-inoculation (dpi); (b) the gills 11 dpi; (c) the skin $11 \mathrm{dpi}$; (d) the heart $11 \mathrm{dpi}$ 

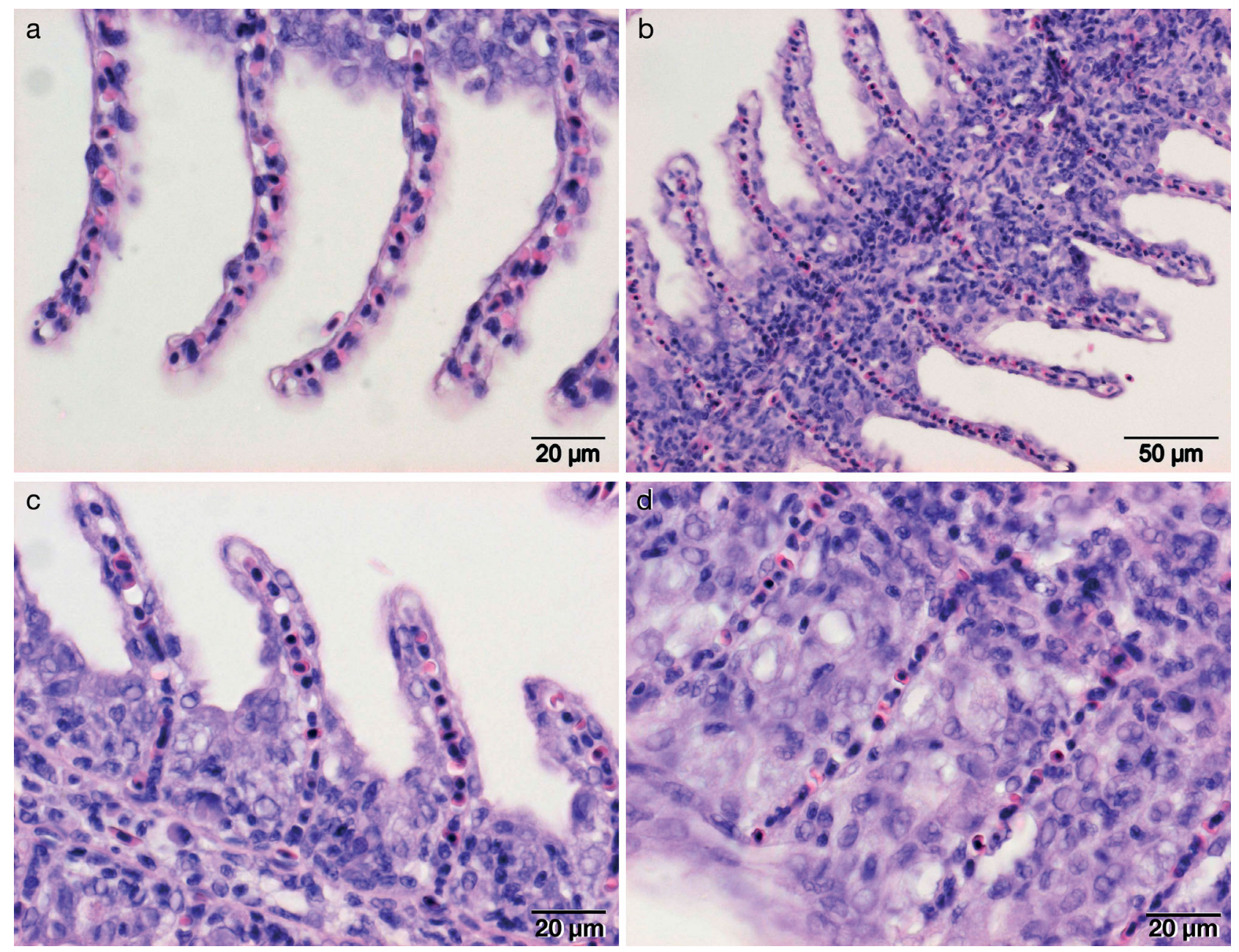

Fig. 3. Anguilla anguilla. Histopathological changes in the gills of juvenile European eel after bath infection with Herpesvirus anguillae (HVA). (a) Gills of negative control eels at Day 3 before virus infection with no abnormalities; (b) HVA-inoculated eels at Day 11 post-inoculation (pi) show gill hyperplasia of the secondary lamellae; (c,d) HVA-infected eels at Day 16 pi with more severe hyperplasia of the secondary lamellae

lum and ventral surface from Day 3 pi, followed by haemorrhages in the skin of the head, lower jaw, operculum and pectoral fins at Day 11 pi. During the later stages, haemorrhages on the ventral surface extended to the tail. These observations resemble data from naturally infected European eel reported by Davidse et al. (1999), although in our study no cutaneous lesions were found. These results indicate that the natural infection route of HVA in European eel is horizontal, via the water. Sano et al. (1990) found necrotic skin lesions in naturally infected Japanese eel. Kobayashi \& Miyazaki (1997) found ulcerative cutaneous lesions after $9 \mathrm{~d}$ post intracutaneous injection in Japanese eel. Lee et al. (1999) found dermal haemorrhagic lesions at the intramuscular injection site and slight haemorrhage in the central region of some gill filaments of juvenile Japanese eels.
The eels of the HVA-infected group were positive in the HVA PCR (at Day 1 pi) 6 d earlier than by virus isolation; therefore, the PCR test was more sensitive, as expected (Rijsewijk et al. 2005), indicating that it is a good tool for the diagnosis of naturally infected eels with HVA. It is not clear, however, if the PCR was positive in the first days after bath immersion due to the HVA suspension remaining in or contaminating the eel mucus and gills, as whole eel trans-sections were used for virus isolation. The virus could be re-isolated from Day 7 pi, with a peak at Day 14 pi, clearly demonstrating that viral replication had occurred.

In the present study, there was a good correlation between the presence of clinical signs and positive immunohistochemistry results. The pathogenesis pattern of HVA in European eel after bath infection appeared to start in the skin and stomach (Day 4 pi), 
then the gills are infected (from Day 7 pi), followed by the heart (Day $11 \mathrm{pi}$ ), the inner operculum, gill cavity, and skin epithelium (Day 14 pi), with the peak of virus replication at Day 14 pi. Only later was the intestine (Day 21 pi) found to be positive for HVA. Therefore, although HVA is known to be involved in gill and skin disease (Sano et al. 1990), the pathogenic route was skin and stomach first, then only the gills and gill cavity, followed by the internal organs such as heart and intestine. However, in our study, gills were found positive in most (11 out of 16) of the clinically diseased eels. From Day 18 to 21 pi, a possible second wave of HVA infection might have occurred as new HVA virus particles, resulting from the peak of the first wave of infection at Day 14 to16 pi, were released into the water. This could partly explain the negative virus isolation results at Day $18 \mathrm{pi}$, and the presence of virus in the skin and intestine in our study, as detected by immunohistochemistry. HVA may be primarily shed from the gills of infected eels as seen by the increased HVA detection in the gills at Days 14 to 16 pi.

Shih et al. (2003) found gills and liver of juvenile Japanese eels positive for HVA by in situ hybridization at Day 28 post intraperitioneal injection only, but no histopathological changes were seen in these eels. Although they used a low dose of HVA, approximately $10^{2.25} \mathrm{TCID}_{50}$ eel $^{-1}$, it seems from our study that the waterborne route with a higher dose is more effective than injection. This might also be an effective route for administering a possible HVA vaccine in the future.

With respect to histopathology, HVA-infected eels from our study showed infiltrations of mononuclear cells in the skin, and mild gill hyperplasia at Day 4 pi. Lee et al. (1999) found necrosis of gill filament connective tissue with infiltrations and oedema, with minute haemorrhages, at Days 5 to $10 \mathrm{pi}$, in intramuscular HVA-inoculated juvenile Japanese eel. Pikarsky et al. (2004), studying another herpesvirus, koi herpesvirus CNGV (carp interstitial nephritis and gill necrosis virus), found the first pathological changes in the gills and kidney of koi Cyprinus carpio from Day 2 pi after bath exposure. From Day 6 pi, the blood vessels were congested, the liver showed inflammatory infiltrates, and the brain showed focal meningeal and parameningeal inflammation. We found no histopathological changes in the brain of HVA-infected eels during the course of the experimental infection reported here.

Hedrick et al. (2000) exposed Cyprinus carpio to a bath of $10^{3.1-3.8}$ TCID $_{50}$ koi herpesvirus $\mathrm{ml}^{-1}$ water at $23^{\circ} \mathrm{C}$ for $2 \mathrm{~h}$. Koi stopped feeding at Day 3 pi, showed lethargy at Day 4 pi, and died from Day 10 pi onwards. Histopathology, demonstrated by infected koi, was predominantly necrosis of the branchial epithelium with nuclear inclusion bodies. In the present study we did not see inclusion bodies in the gills, but further development of haemorrhages in the skin and gill hyperplasia were observed from Day 9 pi, including congestion of the gill cavity from Day 11 pi. Kobayashi \& Miyazaki (1997) also reported skin necrosis with cellular infiltrations in subcutaneous adipose tissue and lateral musculature at Day 11 pi, but this was after intracutaneous injection of HVA in Japanese eels. At Day 13 pi they observed erosive cutaneous lesions at the injection site, with a necrotic dermis, infiltrated by inflammatory cells; the necrotic dermis is similar to the findings of the present study.

In the present study, from Day 11 pi other inner organs showed pathological changes: haemorrhages in the adipose tissue, mild kidney necrosis, and hyperaemia in the muscle. From Day 16 pi mild liver necrosis, and from Day 18 pi mild splenic necrosis were seen. However, we did not find evidence of virus by immunohistochemistry at these sites. The sampled eels from the negative control group showed no histopathological changes during the entire experiment.

Based on our results, it is recommended that clinical signs, virus isolation, and/or PCR be used for detection and diagnosis of HVA infections in eel, as these are less labour-intensive and more sensitive than immunohistochemistry and histological examination. These latter methods can be used as additional, optional procedures but are considered more suitable for in-depth research.

In general it is difficult to compare the present pathogenicity study with other published studies, as we used European, not Japanese, eel, and the eels were infected by bath exposure. Nevertheless, we can conclude that in both Japanese and European eel HVA infection predominantly causes skin and gill lesions.

A typical characteristic of herpesviruses is a latent stage in the host tissue (Hill 1985). HVA was not found in neural tissue throughout the study, although neural tissue may often be a site of latent virus residence in other herpesviruses (Hill 1985). A probable latent nature of HVA was reported by Van Nieuwstadt et al. (2001), but as the eels did not demonstrate disease, it was not fully proven. Due to the short duration of the experiment $(22 \mathrm{~d})$, our study was not designed to examine the possible latent nature of HVA. Stingley et al. (2003) proved latency of channel catfish virus (CCV) in blood of channel catfish by nested PCR $23 \mathrm{wk}$ after bath immersion. However, from our results, skin and gills are candidate target tissues for HVA in the short or longer terms. It is likely that experiments of about $7 \mathrm{wk}$ or longer are needed to study the latency of HVA in eel.

Acknowledgements. The authors thank F. Rijsewijk, B. Verstraten, S. Dijkstra and P. van Tulden for their technical help related to the analysis of samples. 


\section{LITERATURE CITED}

Bourne JA (1983) Handbook of immunoperoxidase staining methods. DAKO Corporation, Santa Barbara, CA

Chen SN, Ueno Y, Kou GH (1982) A cell line derived from Japanese eel (Anguilla anguilla) kidney. Proc Natl Sci Counc Repub China Part B 6:93-100

Davidse A, Haenen OLM, Dijkstra SG, Van Nieuwstadt AP, Van der Vorst TJK, Wagenaar F, Wellenberg GJ (1999) First isolation of herpesvirus of eel (Herpesvirus anguillae) in diseased European eel (Anguilla anguilla) in Europe. Bull Eur Assoc Fish Pathol 19(4):137-141

Evans AS (1976) Causation and disease: the Henle-Koch postulates revisited. Yale J Biol Med 49(2):175-195

Haenen OLM, Dijkstra SG, van Tulden PW, Davidse A, van Nieuwstadt AP, Wagenaar F, Wellenberg GJ (2002) Herpesvirus anguillae (HVA) isolations from disease outbreaks in cultured European eel, Anguilla anguilla in The Netherlands since 1996. Bull Eur Assoc Fish Pathol 22(4):247-257

Hedrick RP, Sano T (1989) Herpesviruses of fishes. In: Ahne W, Kurstak E (eds) Viruses of lower vertebrates. SpringerVerlag, Munich, p 161-170

Hedrick RP, Gilad O, Yun S, Spangenberg JV and 5 others (2000) A herpesvirus associated with mass mortality of juvenile and adult koi, a strain of a common carp. J Aquat Anim Health 12:44-57

Hill TJ (1985) Herpes simplex virus latency. In: Roizman B (ed) The herpesviruses, Vol 3. Plenum, New York, p $175-240$

Kobayashi T, Miyazaki T (1997) Characterisation and pathogenicity of a herpesvirus isolated from cutaneous lesion in Japanese eel, Anguilla japonica. Fish Pathol 32(2):89-95

Editorial responsibility: Marc Crane,

Geelong, Victoria, Australia
Lee NS, Kobayashi J, Miyazaki T (1999) Gill filament necrosis in farmed Japanese eels, Anguilla japonica (Temminck \& Schlegel), infected with Herpesvirus anguillae. J Fish Dis 22:457-463

Pikarsky E, Ronen A, Abramowitz J, Levavi-Sivan B and 6 others (2004) Pathogenesis of acute viral disease induced in fish by carp interstitial nephritis and gill necrosis virus. J Virol 78(17):9544-9551

Rijsewijk F, Pritz-Verschuren S, Kerkhoff S, Botter A, Willemsen M, van Nieuwstadt A, Haenen O (2005) Development of a polymerase chain reaction for the detection of Anguillid herpesvirus DNA in eels based on the herpesvirus DNA polymerase gene. J Virol Methods 124:87-94

Sano M, Fukuda H, Sano T (1990) Isolation and characterisation of a new herpesvirus from eel. Pathol Mar Sci 1:15-31

Shih HH, Hu CW, Wang CS (2003) Detection of Herpesvirus anguillae infection in eel using in situ hybridization. J Appl Ichthyol 19:99-103

Stingley RL, Griffion BR, Gray WL (2003) Channel catfish virus gene expression in experimentally infected channel catfish, Ictalurus punctatus (Rafinesque). J Fish Dis 26: 487-493

Ueno Y, Kitao T, Chen SN, Aoki T, Kou G (1992) Characterisation of a herpes-like virus isolated from cultured Japanese eels in Taiwan. Fish Pathol 27:7-17

Ueno Y, Shi JW, Yoshida T, Kitao T, Sakai M, Chen SN, Kou $\mathrm{GH}$ (1996) Biological and serological comparisons of eel herpesvirus in Formosa (EHVF) and Herpesvirus anguillae (HVA). J Appl Ichthyol 12(1996):49-51

Van Nieuwstadt AP, Dijkstra SG, Haenen OLM (2001) Persistence of herpesvirus of eel Herpesvirus anguillae in farmed European eel Anguilla anguilla. Dis Aquat Org 45:103-107

Submitted: December 8, 2006; Accepted: July 16, 2007

Proofs received from author(s): October 11, 2007 